(C) 1991 ISIJ

"1/IIIIIIIIIIIII!

論 文

|IIIIIIIIIIIIIII!

黒鉛炬原子吸光法による鉄鋼中微量元素の定量

\author{
小林 㴊* - 井出 䄮和 $*$. 大河内春少 $* 2$ \\ 安彦 兼次 ${ }^{* 3}$. 木村㝐*4
}

\title{
Determination of Trace Elemements in Iron and Steels by Graphite Furnace Atomic Absorption Spectrometry
}

Takeshi KoBayashi, Kunikazu IDE, Haruno OKochI,

Kenji ABIKo and Hiroshi KIMURA

Synopsis :

An analytical method has been established for the determination of trace amounts of bismuth, cadmium, cobalt, copper, indium, manganese, nickel, lead and thallium in iron and steels by graphite furnace AAS. The iron and steels were dissolved in nitric acid. After the solution $(20 \mu \mathrm{l})$ was pipetted into a L'vov platform furnace, it was ashed and then atomized by using argon as a purge gas, and atomic absorption of each analyte was measured. The effect of diverse elements was suppressed by the use of peak area measurement. Synthetic calibration solutions were prepared by adding each analyte standard solution to iron matrix solutions. For bismuth, cadmium, cobalt, copper, indium, manganese, nickel, lead and thallium, limit of detection ( $3 \sigma$ of blank values) were $0.15 \mathrm{ppm}, 0.004 \mathrm{ppm}, 0.05 \mathrm{ppm}, 0.07 \mathrm{ppm}, 0.1 \mathrm{ppm}, 0.04 \mathrm{ppm}$, $0.08 \mathrm{ppm}, 0.1 \mathrm{ppm}$ and $0.12 \mathrm{ppm}$, respectively, when one gram of the specimen was used.

Key words : graphite furnace AAS ; iron and steels; determination of $\mathrm{Bi}, \mathrm{Cd}, \mathrm{Co}, \mathrm{Cu}, \mathrm{In}, \mathrm{Mn}, \mathrm{Ni}, \mathrm{Pb}$ and $\mathrm{Tl}$; trace analysis.

\section{1. 緒言}

近年，高純度罁の研究並びにそれらの浴製技術の開発 研究が活発に推進され，高純度鋼に関する研究部会が活 動した ${ }^{1)}$.これらの研究開発に関連して, 微量分析にお ける足量下限及び分析精度の问上が強く要望されてい る。そこで黑鉛炉原子吸光法による鋼中微量成分定量法 の確立を目的として研究を行った。

黒鉛炉原子吸光法は，原子蒸気が限られた狭い場所で 生成されるため高い感度が得られる，著者らは L'vov プラットフォーム文を使用し，熱的に優位な STPF (Stabilized Temperature Platform Furnace) 法 ${ }^{3)}$ を利 用する黑鉛炉原子吸光法による-連の研究を行っている が，其存元素の十涉抑制，分析精度，同一黑鉛炉の多数 回測走等に優れた結果を得ている ${ }^{4) 5)}$.そこで本法の適 用を検討した。本研究では, 呮差因子としての污染を避 けるという観点から分離を行わず，同一試料溶液からの

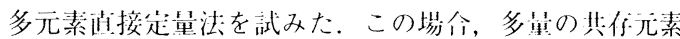
が存在し，その影響が考えられる。したがって，其你元 素に起因する十渉の抑制法と效渗原子化法及び各種酸 の影響を検漷した。更にバックグラウンド（BG）補正 に関し，父流磁場を用いるゼーマン法と速繶光を用いる 方法を比較するため，间一分光器による測定を狱みた。 その他，測走条作等を眊紼に検时した。その綃果，十 涉を除去あるいは抑制し，鉄及び铜ゆの微星 $\mathrm{Bi}, \mathrm{Cd}$, $\mathrm{Co}, \mathrm{Cu}, \mathrm{In}, \mathrm{Mn}, \mathrm{Ni}, \mathrm{Pb}$ 及び $\mathrm{Tl} の$ 简精度で迅速な 起㫣法を確立した。

\section{2. 実}

\section{験}

\section{$2 \cdot 1$ 装置}

原子吸光分析装莦は Perkin-Elmer 社製 Z5100 型原 子吸光光度計と, ゼーマン (父流磁们) BG 補正専用と 連続光（光源は 190 300 $\mathrm{nm}$ は $\mathrm{D}_{2}$ 放電ランプ, 300 $900 \mathrm{~nm}$ は $\mathrm{W}$ ランプ）を用いる BG 補正専用の 2 台の

为 3 年 3 月 11 H受付 (Received Mar. 11, 1991)

* 金属材料技術研究所 (National Research Institute for Metals, 2-3-12 Nakamegro Megro-ku, Tokyo 153)

*2 金属材料技術研究所 T博 (National Research Institute for Metals)

*3 束北大学金属材料研究所 I. 博 (Institute for Materials Research, Tohoku University)

*4 東北大学金属材料研究阮 (現: 神苯川大学: ]博 (Institute for Materials Research, Tohoku University, Now Kanagawa University) 
Table 1. Operating parameters ${ }^{\mathrm{a})}$ of atomic absorption measurement.

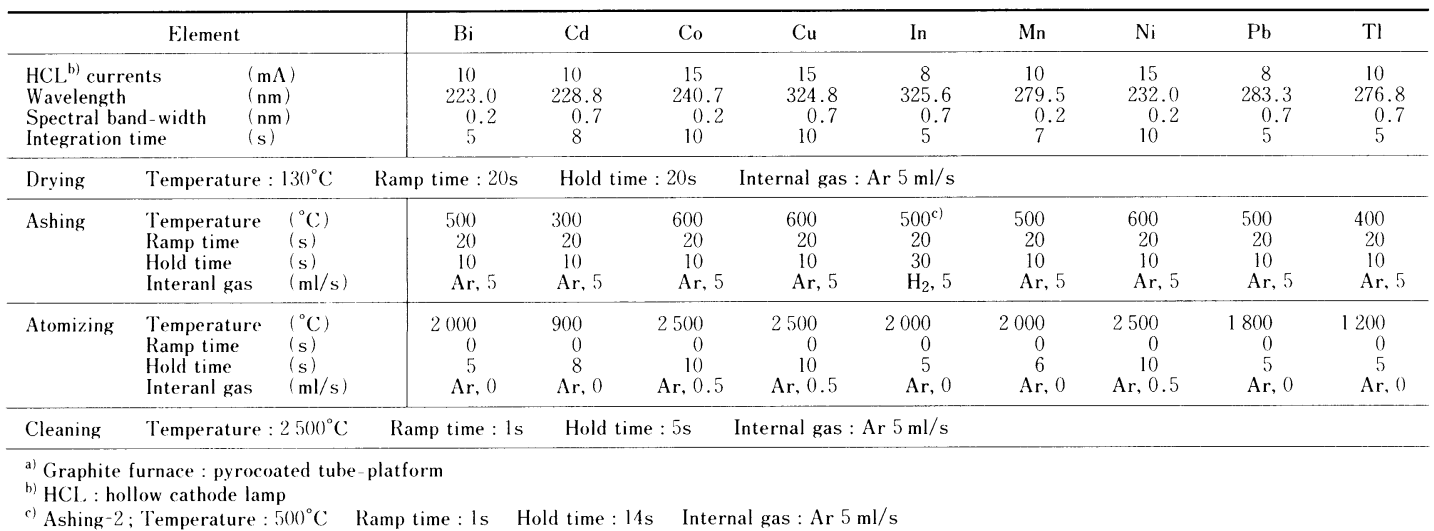

HGA-600 型黑鉛炏原子化装罚を用いたここれらの黒鉛 炉には书の拉のに AS-60 型オートサンプラーを取り付 けた。光源はいずれの无絭も中空陰極管を用いた，黑鉛 炉にはパイロコーティング黑鈆管または同管にL'vov プラットフォームを取り付けて用いた。

\section{$2 \cdot 2$ 試薬}

$\mathrm{Cd}$ 標隻溶液 $1 \mathrm{mg} / \mathrm{ml}$ は熍純度金盾 Cd (Johnson Matthey Chemicals 社製，以ト JMC と略㲹） $1.000 \mathrm{~g}$ を少量の塩酸を用いて加熱分解し，泠却後 $1 \%(\mathrm{v} / \mathrm{v})$ 塩 酸で 11 とした．Tl槽準溶液 $1 \mathrm{mg} / \mathrm{ml}$ は硝酸夕リウム $\left(\mathrm{TINO}_{3}\right) 1.303 \mathrm{~g}$ を蒸留水で溶解し，11 とした。 In 標 準溶液は既報 ${ }^{4 〉}$ と间様に洞製した。 $\mathrm{Bi} ， \mathrm{Co}, \mathrm{Cu}, \mathrm{Mn}$, $\mathrm{Ni}$ 及び $\mathrm{Pb}$ は, JIS G 1257 鉄及び鋼の原子吸光分析方 法」6)に準じて夙製した。使用時にこの原液を水で希䣋 して用いた，使用した高純度金属は，東北大学金禹材料 研究所において電解鉄を純化した高純度鉄 (残留抵抗比 $\mathrm{RRR}_{\mathrm{H}}$ は 1400$) ， \mathrm{JMC}$ の $\mathrm{Ni}$ 及び $\mathrm{Cr}$ を用いた。酸類 はすべて原子吸光分析用を使用した。パージガスには超 高純度 $\mathrm{Ar}(99.999 \%)$ と $\mathrm{H}_{2}(99.5 \%)$ を使用した。

\section{$2 \cdot 3$ 実験操作}

高純度鉄 $1.0 \mathrm{~g}$ をビーカー $(300 \mathrm{ml})$ にはかり取り， 硝酸を用いて熱板上で加熱分解し，冷却後，分析元素の 標潐溶液を一走星添加してメスフラスコに移し人れ 100 $\mathrm{ml}$ 足行とした。この溶液 $20 \mu \mathrm{l}$ をオートサンプラーで 黑鉛炊内に注人し，Table 1 に亦す条作で吸光度を測是

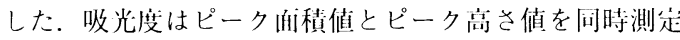
し，同一溶液を 4 泪测定してその将均值を用いた。本 法による炎化ステップから原子化ステップへの昇温時䦌 (ランプ時间)：0s は Maximum power mode で昇温し, その昇温速度は約 $2000^{\circ} \mathrm{C} / \mathrm{s}$ である. また, 以降の尖 験に用いた溶液の䑩製後の濃度は特に表示しない場今，
$\mathrm{Cd} 0.001 \mu \mathrm{g} / \mathrm{ml}$, その他の元素は $0.05 \mu \mathrm{g} / \mathrm{ml}$ とした. $\mathrm{Fe}$ 濃度は $10 \mathrm{mg} / \mathrm{ml}$, 硝酸は約 $1.5 \mathrm{M}$ で行った。

\section{3. 実験結果と考察}

\section{$3 \cdot 1$ 灰化条件の検討}

検討に用いた溶液は， $2 \cdot 3$ でホしたように淍製した。 L'vov プラットフォームを取り付けた黑鉛炉内に溶液を 注人し, Table 1 に示した条作で測定し，火化温度を变 化させたときの，吸光度との関係線 (炎化温度曲線) を 作成した。一例として Fig. 1 に Cd の炏化温度曲線を 示す。黒鉛炏は使用回数の増加に伴い黑鉛が酸化等の消 耗により劣化し，抵抗値に変化が生じ，初期設起温度が 高温側に移動する7)。したがって，一走の吸光度を茹定 して得らる疢化温度域が必要となる。これらを考虑して,

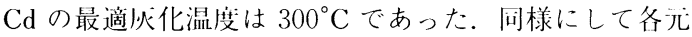
素の最適炏化条作を Table 1 のように定めた。しかし，

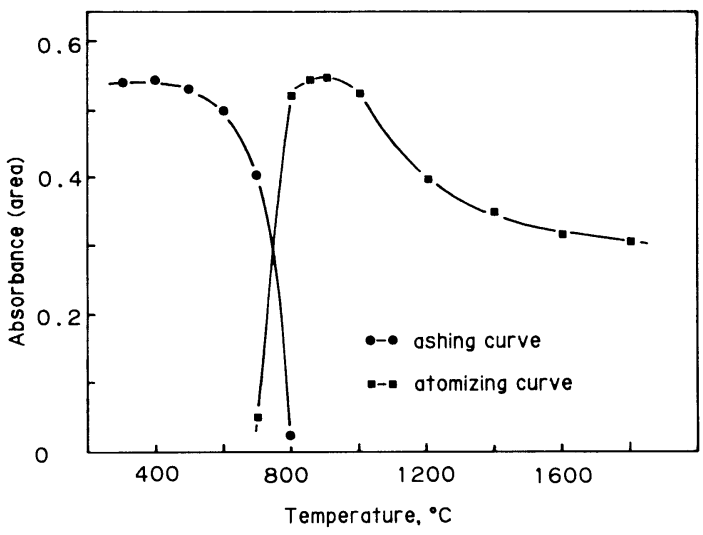

Fig. 1. The effect of ashing and atomizing temperatures on the absorbance of cadmium. 
In の場令 Fig. 2 に示すようにパージガスに Ar を用い ると低い吸光度を示す。これは, In が比較的高温でも 安定な InO を生成して Ar 雲囲気中では熱分解しない ことと,この温度では使用したパイロリティック黑鎦で の C または COによる還元が弱いため分子状で蒸発捕 散したものと考えられる。このことを確認するため, 分子吸収の測定を試みた。測定は既報")に準じて行っ た， InOの分子吸収は感度が悪いため Fe の硝酸溶液に

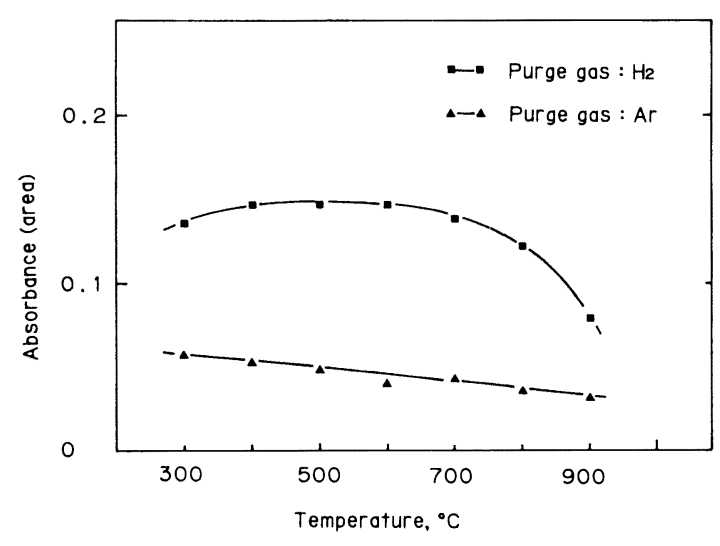

Fig. 2. The effect of ashing temperatures on the absorbance of indium in the iron solution.

Table 2. Operating parameters of molecular absorption measurement.

\begin{tabular}{|c|c|c|c|}
\hline \multicolumn{2}{|c|}{$\begin{array}{l}\text { Light source } \\
\text { Spectral band-with } \\
\text { Measurement } \\
\text { Integration time }\end{array}$} & \multicolumn{2}{|c|}{$\begin{array}{l}\text { Deuterium arc lamp } \\
0.7 \mathrm{~nm} \\
\text { Peak-area } \\
3 \mathrm{~s}\end{array}$} \\
\hline Step & Temperature $\left({ }^{\circ} \mathrm{C}\right)$ & Ramp time (s) & Hold time (s) \\
\hline $\begin{array}{l}\text { Dring } \\
\text { Ashing } \\
\text { Atomizing a) } \\
\text { Cleaning }\end{array}$ & $\begin{array}{r}130 \\
500 \\
2000 \\
2500\end{array}$ & $\begin{array}{r}20 \\
20 \\
0 \\
1\end{array}$ & $\begin{array}{r}20 \\
10 \\
3 \\
5\end{array}$ \\
\hline
\end{tabular}

Inを添加し, In 濃度を $80 \mu \mathrm{g} / \mathrm{ml}$ に洞製した。分子吸収 の測定は Table 2 に示す条件で 190〜280 nm の範囲で 行った。その結果は Fig. 3 にホしたように, 203 及び $275 \mathrm{~nm}$ 付近に $\mathrm{InO}$ の分子吸収を確認した。この結果は, DitTRICH $^{8)}$ の報告した InO の叫収と一致した。このこと は $\mathrm{InO} の 一$ 部は $2000^{\circ} \mathrm{C}$ の高温でも解離しないことを 示唆している。そこで必化時のみパージガスに還元力の 強い $\mathrm{H}_{2}$ を使用することを検测した。その結果 Fig. 2 に示すように $400 \sim 700^{\circ} \mathrm{C} に$ にいて一分した高い吸光度 が得られた。この条作によれば $\operatorname{InO} の$ 分子吸收も完全 に消失していたここれらのことは发分な $\mathrm{InO} て ゙ も \mathrm{H}_{2}$ 還元によって必化が十分に行われたものと考察された。

以上の結果から In の最適必化条件はパージガスに $\mathrm{H}_{2}$ を用いて必化温度 $500^{\circ} \mathrm{C}$ ランプ時间 $20 \mathrm{~s}$, 保持時間 $30 \mathrm{~s}$ と走めた。な拉， $\mathrm{H}_{2}$ を令む状態で原子化すると， 黑鉛炉の消耗が激しいため, Ar ガスによる残你 $\mathrm{H}_{2}$ の 除去ステップを設けた。

\section{$3 \cdot 2$ 原子化条件の検討}

原子化条件の検封による $3 \cdot 1$ で用いた溶液を使用 し, $3 \cdot 1$ と闹様に原子化温度を变化させ，吸光度との関 係線（原子化温度曲線）を求めたＦＦ．１に 1 Cdの原子 化温度曲線を亦す。 $\mathrm{Cd}$ の原子收光シグナルは $700^{\circ} \mathrm{C}$ 付 近から出現し， $800 \sim 1000^{\circ} \mathrm{C}$ の範䎴で・分した高い吸 光度となり，それ以上の温度では徐々に吸光度が低下す る。この結果から， $\mathrm{Cd} の$ 最適原子化温度は $900{ }^{\circ} \mathrm{C}$ と 足めた。闹様にして求められた齐少素の最適原子化温度 を Table 1 に亦した。た，愿子化終了後の残仔成分 の除去は $2500^{\circ} \mathrm{C}$ で $5 \mathrm{~s}$ 行った。

更に，L'vovプラットフォームの效果を確軔するため に黑鉛炉内の L'vov プラットフォームトから原子化し た場令と黒鈆管壁から原子化した場令での Fe 溶液中の $\mathrm{Pb}$ の原子吸光一時阔プロファイルを测分した。結果を Fig. 4 に示す. $500^{\circ} \mathrm{C}$ で必化後, 穼子化ステップの開

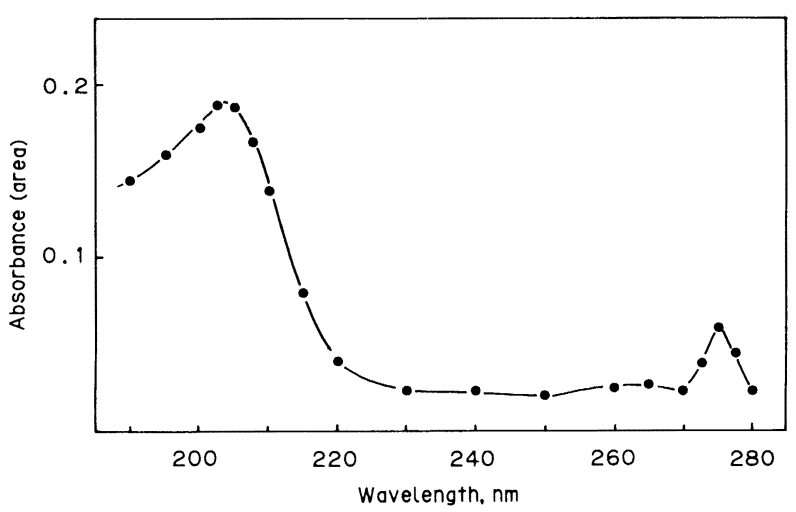

Fig. 3. Molecular spectrum at $190 \sim 280 \mathrm{~nm}$ region for indium oxide. 


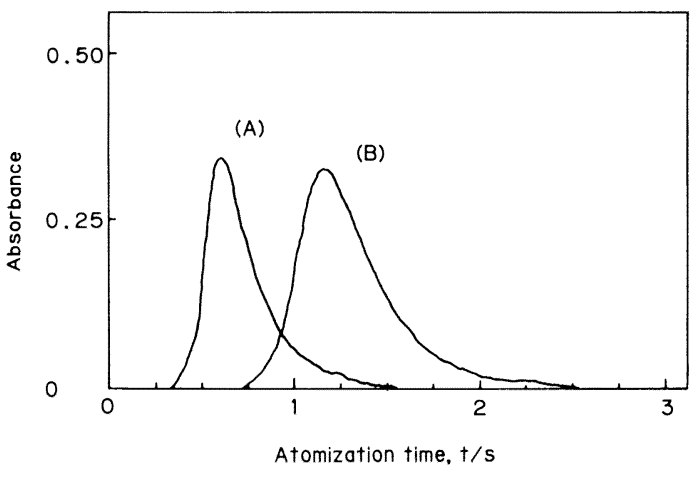

(A) From wall of pyrolytically coated graphite tube (B) From platform

Fig. 4. Atomic absorption-time profiles for lead in iron solution.

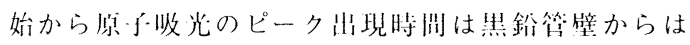

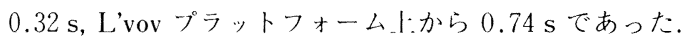

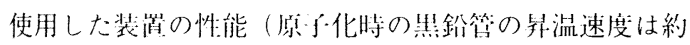

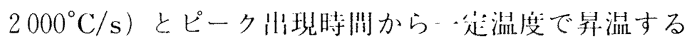

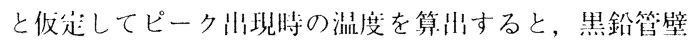

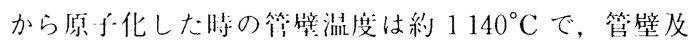
び㶧内のガス温度はまだ最温段階である。・方, L'vov プラットフォームはから面子化の場令，ピーク出現時の 管壁温度は $1980^{\circ} \mathrm{C}$ となり，管壁及びガス温度は既に

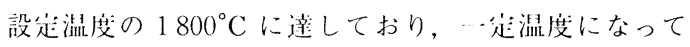
いると考えられる。したがって L'vov プラットフォー ム上から原子化を行うことで, 原子化時の温度は高温で, かつ怕埧状態でありガス膨银による目的元素の系外への

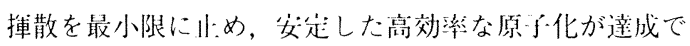
きたと推祭された。

\section{$3 \cdot 3$ 試料液性の検討}

本法による試料分解法は適用鋼種が高純度鉄，低令食 鋼や炭素鋼であれば硝酸による分解法が望ましい。しか し，ステンレス鋼等は硄酸のみでは分解しない。した がって王水系またはそれ以外の酸を用いる必要がある。 その場令, 塩化物イオンやふっ化物イオン等のハロゲン 化物による十涉がケ想される。 そこで各元素の收光度に 及ぼす液性の影響を検封した。 Feの各種酸溶液を Table 3 に亦すように調製し, Table 1 に示した条俶で 測定した。 その結果, 硝酸浴液については In 以外の元 素は特に閣題点はみられなかったＩnについては $3 \cdot 1$ で示したように必化時に $\mathrm{H}_{2}$ を通気することで解決し た。更に，王水系の溶液の場令 Cd, In 及び Tlではほ とんど吸光度を検出できなかった。また，Inは硫酸溶
Table 3. Effect of acid on the absorbance of each analyte in iron solution.

\begin{tabular}{|c|c|c|c|c|c|c|c|c|}
\hline Element & $\mathrm{Bi} \quad \mathrm{Cd}$ & Co & $\mathrm{Cu}$ & In & $\mathrm{Mn}$ & $\mathrm{Ni}$ & $\mathrm{Pb}$ & $\mathrm{Tl}$ \\
\hline $\begin{array}{l}\mathrm{HNO}_{3}(1.5 \mathrm{M}) \\
\mathrm{HNO}_{3}(0.8 \mathrm{M})+\mathrm{HCl}(1.2 \mathrm{M}) \\
\mathrm{H}_{2} \mathrm{SO}_{4}(2 \mathrm{M}) \\
\mathrm{HF}(1 \mathrm{M})+\mathrm{HNO}_{3}(1 \mathrm{M}) \\
\mathrm{H}_{3} \mathrm{PO}_{4}(0.2 \mathrm{M})\end{array}$ & $\begin{array}{l}3 \\
\Delta \\
\Delta\end{array}$ & 3 & $\Delta$ & $\begin{array}{l}()^{a)} \\
\times \\
x \\
()^{a)}\end{array}$ & $\Delta$ & 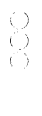 & $\Delta$ & $x$ \\
\hline
\end{tabular}

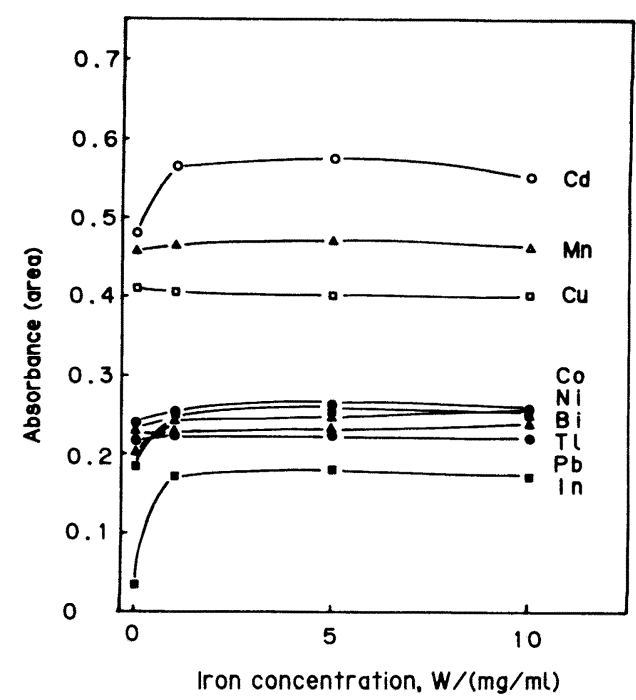

Fig. 5. The effect of iron concentration on the absorbances (peak-area) of each analyte.

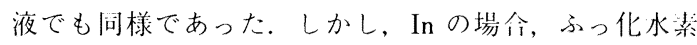
酸一硝酸系溶液とし，必化時にパージガスとして $\mathrm{H}_{2}$ を 通気することで高い吸光度が得られた。

以上の結果より, 試料溶液が硝酸以外の場令, |闹…溶 液からでは本研究で検討した 9 元素を測羑することは 困難であることが判明した。

\section{$3 \cdot 4$ 共存元素の影響}

主成分の $\mathrm{Fe}$ 濃度について調べた。 Fe 濃度が0〜10 $\mathrm{mg} / \mathrm{ml}$ の浴液を洞製し，黑鉛灯内にL'vov プラット フォームを取り付けTable 1 の条件で測定した。測足 をピーク面積值で行った場令の結果を Fig. 5, ピーク 高さ值での測定結果をFig. 6 に示した。これらの結果 からほとんどの元素について，Fe を含まない場令は ピーク面積值及びピーク高さ值其に低い吸光度である が, $\mathrm{Fe}$ 濃度が $1 \mathrm{mg} / \mathrm{ml}$ では高くなる。このことは $\mathrm{Fe}$ が目的元素の原子化を遅らせることでより高温で原子化 が行える符マトリックス修飾試薬的作用をしているも 


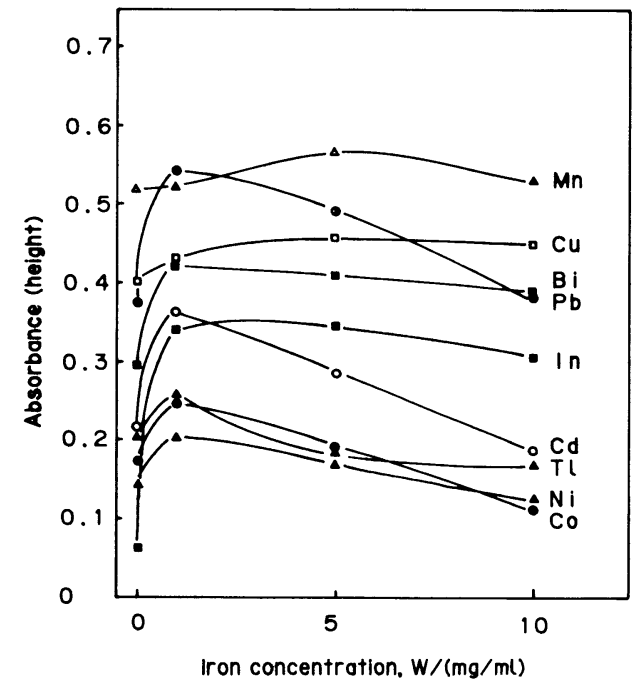

Fig. 6. The effect of iron concentration on the absorbances (peak-height) of each analyte.

のと考える。更に，ピーク涌積值ではFe 濃度 1 ～10 $\mathrm{mg} / \mathrm{ml}$ の範囲でほとんど一定の吸光度を示した。しか し，ピーク高さ值では $\mathrm{Fe}$ 濃度の增加と其にほとんどの 光素の吸光度は低下した。これらの結果から，胃鏑灯内 にL'vovプラットフォームを取り付け，ピーク证積储 で測定を行えば検量線溶液の $\mathrm{Fe}$ 濃度を試料溶液より低 くすることが川能で，ブランク値の低下などが行える. たとえば，検量線作成浴液の $\mathrm{Fe}$ 濃度を $1 \mathrm{mg} / \mathrm{ml}$ とし, 試料溶液のマトリックス濃度を $10 \mathrm{mg} / \mathrm{ml}$ とすることが 川能であることが判明した。

適用鋼種をステンレス鋼とした場命， $\mathrm{Ni}$ 及び $\mathrm{Cr}$ を多 單に含有する。これらの基你元素の影響を調べた。主成 分である。 Feに Ni が 10 質量\%または 30 質重\%其你 寸る硝酸浴液に分析元素の標準溶液を一定量添加した溶 液と添加しないから試験液を調製した。これらの溶液を 測定し, $\mathrm{Fe}$ のみの場令と比較した。絬果はTable 4 に 亦すようにピーク宫さ值では Co 以外は $\mathrm{Ni}$ の影響を受 ける，特にCdに対する影響が大きく，比較的蒸気厯の 高い元素に対して正の十涉を与える。一方，ピーク面積 值では $\mathrm{Tl}$ 以外の元素では $\mathrm{Ni}$ が 30 質量\%共存しても干 涉は $\pm 5 \%$ 以内であった。更に， Crの影響を調べた。 $\mathrm{Cr}$ の場合，液性は塩酸 $1.2 \mathrm{M}$ と硝酸 $0.8 \mathrm{M}$ の王水系と し，Niの場令と间様に調製した。結果を Table 5 に示 す. $\mathrm{Cr}$ も $\mathrm{Ni}$ と闹様に 30 質量\%其仔した場令, 测定し た 6 元素いずれもピーク高さ值に影響した。 その傾问 は $\mathrm{Ni}$ の場令と间様であり, ピーク面積值では 6 元素い
Table 4. Effect of nickel on the relative absorbance $^{\text {a) }}$ of each analyte in iron solution.

\begin{tabular}{c|cccc}
\hline Element & measurement & $\mathrm{Fe}(10 \mathrm{mg} / \mathrm{ml})$ & $\mathrm{Fe}-10 \mathrm{Ni}$ & $\mathrm{Fe}-30 \mathrm{Ni}$ \\
\hline $\mathrm{Bi}$ & Peak-area & 1.00 & 1.00 & 1.02 \\
& Peak-height & 1.00 & 1.04 & 1.09 \\
$\mathrm{Cd}$ & Peak-area & 1.00 & 1.01 & 1.02 \\
& Peak-height & 1.00 & 1.95 & 3.02 \\
$\mathrm{Co}$ & Peak-area & 1.00 & 1.00 & 1.02 \\
& Peak-height & 1.00 & 1.00 & 0.99 \\
$\mathrm{Cu}$ & Peak-area & 1.00 & 1.01 & 0.90 \\
& Peak-height & 1.00 & 0.93 & 0.85 \\
$\mathrm{In}$ & Peak-area & 1.00 & 0.98 & 0.99 \\
$\mathrm{Mn}$ & Peak-height & 1.00 & 0.96 & 0.92 \\
& Peak-area & 1.00 & 1.02 & 1.05 \\
$\mathrm{~Pb}$ & Peak-height & 1.00 & 1.13 & 1.16 \\
$\mathrm{Tl}$ & Peak-area & 1.00 & 0.99 & 0.97 \\
& Peak-height & 1.00 & 1.09 & 1.10 \\
& Peak-area & 1.00 & 1.06 & 1.12 \\
& Peak-height & 1.00 & 1.04 & 1.10 \\
\hline
\end{tabular}

a) Absorbance of each analyte in iron solution : 1.00

Table 5. Effect of chromium on the relative absorbance $^{a)}$ of each analyte in iron solution.

\begin{tabular}{c|cccc}
\hline Element & measurement & $\mathrm{Fe}(10 \mathrm{mg} / \mathrm{ml})$ & $\mathrm{Fe}-10 \mathrm{Cr}$ & $\mathrm{Fe}-30 \mathrm{Cr}$ \\
\hline $\mathrm{Bi}$ & Peak-area & 1.00 & 0.98 & 0.97 \\
& Peak-height & 1.00 & 1.07 & 1.12 \\
$\mathrm{Co}$ & Peak-area & 1.00 & 1.01 & 1.02 \\
$\mathrm{Cu}$ & Peak-height & 1.00 & 1.02 & 1.06 \\
& Peak-area & 1.00 & 1.01 & 0.98 \\
$\mathrm{Mn}$ & Peak-height & 1.00 & 0.97 & 0.95 \\
$\mathrm{Ni}$ & Peak-area & 1.00 & 1.01 & 1.05 \\
$\mathrm{Ni}$ & Peak-height & 1.00 & 1.15 & 1.20 \\
$\mathrm{~Pb}$ & Peak-area & 1.00 & 1.00 & 0.99 \\
& Peak-height & 1.00 & 0.97 & 0.93 \\
& Peak-area & 1.00 & 0.99 & 0.96 \\
& Peak-height & 1.00 & 1.12 & 1.18 \\
\hline
\end{tabular}

a) Absorbance of each analyte in iron solution : 1.00

ずれもト涉はみられなかった。これらの絬果から，黑䤵 烦に L’vovプラットフォームを取り付けて一尘滥度下 で原子化を行い，史に吸光度をピーク血槕储で測定する ことが其份西によるけ渉の抑制に聂適であることが明

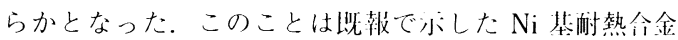

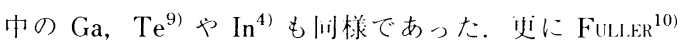
が行った原子の生成過程や榈火事程の熟力学的な理論的 考祭絬果とも一致した。

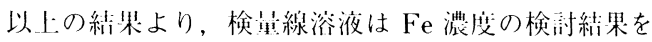
考虑して Fe 濃度 $2 \mathrm{mg} / \mathrm{ml}$ 溶液とし, 分析元素の標準 浴液を添㞦して凰製することとした。

\section{$3 \cdot 5$ 感度及び検出限界}

感度及び検忡限界を調べた。感度は検星線の傾きから 1\%吸収（吸光度 0.0044 ）をふす寸佔に対する冬元素の啠 量を求めた。また検出限界は検虽線のから試験液を 20

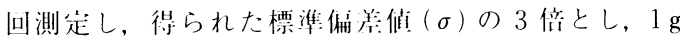
試料中濃度に換算した。史に，BG 補正法の違いによる 感度について间様に㗅べた。絬果を Table 6 に示す。 间一分光器による BG 補正法の違いを比較検湖した。 連続光による補正法は一般的にゼーマン BG 補正法と 比較して感度拥では優机ている。 ゼーマン BG 補正法 
Table 6. Reciprocal sensitivities and detection limit for the determination ${ }^{\text {a) }}$ of each analyte in iron solution used in two background correction methods.

\begin{tabular}{|c|c|c|c|}
\hline \multirow[b]{2}{*}{ Element } & \multicolumn{2}{|c|}{ Zeeman effect ( $\Lambda \mathrm{C}$ magnet) } & \multirow{2}{*}{$\frac{\text { Continuum source }}{\text { Sensitivities }_{(\mathrm{pg})}}$} \\
\hline & $\begin{array}{c}\text { Sensitivities } \\
(p g)\end{array}$ & $\begin{array}{l}\text { Detection limit }{ }^{c)} \\
(\mu \mathrm{g} / \mathrm{g})\end{array}$ & \\
\hline $\mathrm{Bi}$ & 25 & 0.15 & 17 \\
\hline $\mathrm{Cd}$ & 0.4 & 0.004 & 0.38 \\
\hline Co & 8 & 0.05 & 6 \\
\hline $\mathrm{Cu}$ & 9 & (0.07 & 5 \\
\hline In & 14 & 0.1 & 12 \\
\hline $\mathrm{Mn}$ & 3 & 0.04 & 2 \\
\hline $\mathrm{Ni}$ & 10 & 0.08 & 9 \\
\hline $\mathrm{Pb}$ & 13 & 0.1 & 10 \\
\hline $\mathrm{Tl}$ & 10 & 0.12 & 7 \\
\hline
\end{tabular}

a) Calculated for $\mathrm{N}=20$ and $20 \mathrm{ul}$ injections

b) Concentration giving $1 \%$ absorption $(0.0044$ absorbance unit

c) Concentration giving $3 \sigma$ of blank value

でも筫贸ゼーマン分裂篮による感度搷尖の小さい交流 ゼーマン $\mathrm{BG}$ 補正法 $^{11)} に$ に扔いても $\mathrm{Bi}, \mathrm{Cu}$ や $\mathrm{Tl}$ 筡は 感度の提火が大きい。しかし，連続光による補正法では $\mathrm{Bi}, \mathrm{Cd}, \mathrm{Cu}$, In や $\mathrm{Ni}$ 筞で $\mathrm{Fe}$ の近接線や幅の狭い分 子スペクトルの收収または発光スペクトル管に起团する

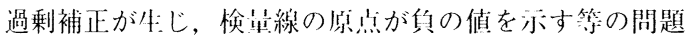
がある。したがって本注のように試料溶液㨁接導人法の

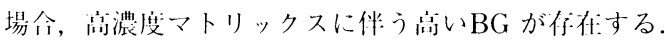

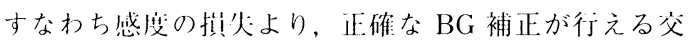
流ゼーマン BG 補正法が坟適であると判断した。

\section{4. 実際試料への応用}

\section{$4 \cdot 1$ 分析方法}

試料はかり取り革を $1.00 \mathrm{~g}$ とし, $300 \mathrm{ml}$ のビーカー を用いて，少里の水と硝酸 $10 \mathrm{ml}$ を加えて熱板上で加熱 分解する。试料を省全に分解し, 冷却後 $100 \mathrm{ml}$ のメス フラスコに移し人れ，水で標線まで希秋する，検量線溶 液は高純度鉄 $2.00 \mathrm{~g}$ を硝酸 $20 \mathrm{ml}$ を用いて觉羊に分解 し, 冷却後 $250 \mathrm{ml}$ のメスフラスコに移し人れ，水で槽 線まで希釈する。この淮液 $25 \mathrm{ml}$ を $100 \mathrm{ml}$ のメスフラ

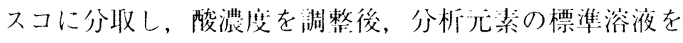
段階的に添㧈して周製する。测足はTable 1 にホした

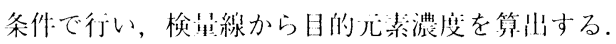

\section{$4 \cdot 2$ 分析結果}

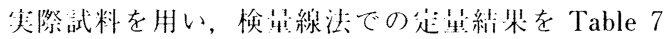
に示す。 ECRM 097-1 では衣小储と良い一致が得られ た。な拈，ECRM 097-1の Co, Cu, Mn 及び $\mathrm{Ni} 5$ 倍に希秋した咸料淮液を朋いた。更に，ECRM 097-1 を用いて 8 湖並行して这错して求めた絬果から得られ た本法の分析精度は，相対槽潗偏施（RSD）として Cu は2.3\%，Pbは4.1\%であり満起できる結果であった。
Table 7. Determination of each analyte in high purity iron.

\begin{tabular}{|c|c|c|c|c|}
\hline \multirow{2}{*}{ Element } & \multicolumn{2}{|c|}{ ECRM 097-1 } & \multirow{2}{*}{$\frac{A}{\substack{\text { This method } \\
(\mathrm{ppm})}}$} & \multirow{2}{*}{ 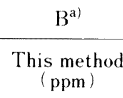 } \\
\hline & $\begin{array}{c}\text { Certified } \\
\text { value (ppm) }\end{array}$ & $\begin{array}{c}\text { This method } \\
(\mathrm{ppm})\end{array}$ & & \\
\hline $\mathrm{Bi}$ & $<5^{\text {b) }}$ & 0.2 & $<0.15$ & $<0.15$ \\
\hline $\mathrm{Cd}$ & & 0.01 & 0.02 & 0.01 \\
\hline Co & 36 & 35 & 0.7 & 0.4 \\
\hline $\mathrm{Cu}$ & 20 & 20 & 2 & 0.2 \\
\hline In & - & $<0.1$ & $<0.1$ & $<0.1$ \\
\hline $\mathrm{Mn}$ & 64 & 62 & 0.8 & 0.2 \\
\hline $\mathrm{Ni}$ & 25 & 24 & 0.4 & 0.1 \\
\hline $\mathrm{Pb}$ & $<5^{\text {b) }}$ & 0.2 & 0.2 & 0.1 \\
\hline $\mathrm{Tl}$ & & $<0.12$ & $<0.12$ & $<0.12$ \\
\hline
\end{tabular}

b) Approximate values

また, 電解鉄を用い純化法の晎なる 2 種類の高純度鉄 (A，B）を定量し，純化度を明らかにした。

\section{5. 結言}

黒鉛炉原子吸光法を鉄鋼中の $\mathrm{Bi}, \mathrm{Cd}, \mathrm{Co}, \mathrm{Cu}, \mathrm{In}$, $\mathrm{Mn}, \mathrm{Ni}, \mathrm{Pb}$ 及び $\mathrm{Tl}$ の定量に適用した。その維果，武 料を硝酸で分解し，その溶液を直接黑鉛灯を用いて原子 化する場命，黑鉛炉内に L'vov プラットフォームを収 り付け一定温度下での原子化と吸光度をピーク而積僧で 測定することでマトリックス濃度や其存元素による十沙 を抑制することができ，间一溶液から多元素分析が行え た。

本法による検出限界は $3 \sigma$ の場命，試料はかり收り量 $1 \mathrm{~g}$ で $\mathrm{Bi}: 0.15 \mathrm{ppm}$, Cd: $0.004 \mathrm{ppm}, \mathrm{Co}: 0.05 \mathrm{ppm}$, $\mathrm{Cu}: 0.07 \mathrm{ppm}$, In : $0.1 \mathrm{ppm}, \mathrm{Mn}: 0.04 \mathrm{ppm}, \mathrm{Ni}: 0.08$ $\mathrm{ppm}, \mathrm{Pb}: 0.1 \mathrm{ppm}, \mathrm{Tl}: 0.12 \mathrm{ppm}$ であり, 正確で迅速 な微量定量法である。

\section{文献}

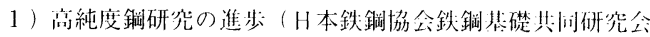

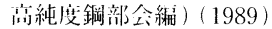

2) B. V. L'vov: Spectrochim. Acta, 33B (1978), p. 153

3 ) W. Si.avin, D. C. Manning and G. R. Carnilck: At. Spectrosc., 2 (1981), p. 137

4 ) 小林 阙, 大测内价少: 月本金属学会比, 53 (1989), p. 1123

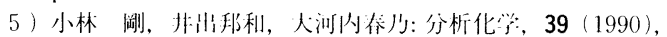
p. 497

6 ) JIS G 1257-1987

7) O. Kujiral, T. Kobayashi and E. Subo: Trans. Jpn. Inst. Met., 18 (1977), p. 775

8) K. Ditтrich: Anal. Chim. Acta, 111 (1979), p. 123

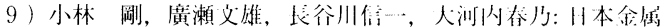
学丟誌, 49 (1985), p. 656

10) C. W. Ful.Lik: Analyst (London), 101 (1976), p. 798

11) F. J. Fernandez, W. Bohit.r, M. M. B B.aty and W. B. BarnktT: At. Spectrosc, 2 (1981), p. 73 